\title{
Activity of Secondary Bacterial Metabolites in the Control of Citrus Canker
}

\author{
Letícia Sayuri Murate', Admilton Gonçalves de Oliveira1, Allan Yukio Higashi', \\ André Riedi Barazetti ${ }^{1}$, Ane Stefano Simionato', Caroline Santos da Silva ${ }^{1}$, \\ Glenda Cavalari Simões ${ }^{1}$, Igor Matheus Oliveira dos Santos ${ }^{1}$, Marlon Renan Ferreira', \\ Martha Viviana Torres Cely ${ }^{1}$, Miguel Octavio Pérez Navarro', Vanessa Fogaça de Freitas ${ }^{1}$, \\ Marco Antonio Nogueira², João Carlos Palazzo de Mello3 ${ }^{3}$ Rui Pereira Leite Jr.4, \\ Galdino Andrade ${ }^{*}$ \\ ${ }^{1}$ Department of Microbiology, Londrina State University, Londrina, Brazil \\ ${ }^{2}$ Embrapa Soja, Londrina, Brazil \\ ${ }^{3}$ Department of Pharmacy and Pharmacology, Maringá State University, Maringá, Brazil \\ ${ }^{4}$ Plant Protection, Agronomic Institute of Paraná, IAPAR, Londrina, Brazil \\ Email: ${ }^{*}$ andradeg@uel.br
}

Received 10 February 2015; accepted 7 March 2015; published 10 March 2015

Copyright (C) 2015 by authors and Scientific Research Publishing Inc.

This work is licensed under the Creative Commons Attribution International License (CC BY). http://creativecommons.org/licenses/by/4.0/

(c) (i) Open Access

\section{Abstract}

This study investigated the protective effects of secondary bacterial metabolites, produced by Pseudomonas sp. (bacterium strain LN), on citrus canker disease caused by Xanthomonas axonopodis pv. citri (Xac 306). The LN bacteria strain was cultured in liquid medium and the supernatant free-cells was treated with methanol (AMF) and ethyl acetate (AEF), respectively, and then the extract was concentrated, filtrated, lyophilized and fractionated by vacuum liquid chromatography (VLC). After VLC, eight fractions were obtained. All fractions' activity against Xac 306 by agar well diffusion assay and minimum inhibitory concentration but in different concentrations were tested. Cytotoxicity effects were observed in all fractions in $50 \mu \mathrm{g} \cdot \mathrm{mL}^{-1}$ concentration. The comet assay demonstrated that the fractions EAF, VLC2 and VLC3 presented no genotoxic effects at tested concentrations. In plants only VLC3 showed significant results $(p<0.05)$, reducing the incidence of citrus canker lesions.

\section{Keywords}

X. axonopodis pv. citri, Citrus sinensis, Antibiosis, Biological Control, Natural Antibiotic

\footnotetext{
${ }^{*}$ Corresponding author.
} 


\section{Introduction}

Citrus canker (CC), caused by the bacterium Xanthomonas axonopodis pv. citri (Xac), is a serious worldwild disease in citrus production [1]. The pathogen causes necrotic lesions on leaves, stems and fruits. Severe infections can cause defoliation, blemished fruits, premature fruit drop, twig dieback, general tree decline [2], and consequent yield decrease. The losses can reach hundreds of millions of dollars per year. Only in Florida, US\$ 200 millions had been spent until 2001, not including the losses with the elimination of contaminated trees and plantlets [3].

The infective process begins with the entrance of Xac through natural openings (stomata) or wounds. Inside the plant, cells of Xac multiply in intracellular space until the spaces become filled with bacteria or exopolysaccharide [4]. The earliest symptoms on leaves appear, under optimum conditions, as slightly raised tiny blisterlike lesions about 4 - 7 days after inoculation [5]. As the lesion ages, they turn brown, and a water-soaked margin appears surrounded by a chlorotic halo.

The methods used to control CC in areas of the world where it is endemic, involves use of resistant varieties of citrus, windbreaks to hinder inoculum dispersal and timely applications of copper-containing bactericides [2]. However, the bacterium can develop resistance to the products, thus demanding an increase of copper application frequency. In addition, there is an increasing concern about the accumulation of such substances in food and in the environment [6]. For these reasons, the use of antagonist bacteria or their metabolites has been proposed as a promising strategy for plant protection [7]-[10].

The aim of this work was to evaluate secondary bacterial metabolites produced by Pseudomonas sp. LN strain on the severity of citrus canker lesion caused in Citrus sinensis cv. Valencia, by isolate 306 of Xac.

\section{Material and Methods}

\subsection{Bacterial Strains}

The pathogen Xanthomonas axonopodis pv. citri 306 strain (Xac 306) whose genome had been sequenced [11], was used in all experiments. This bacterium was stored in $30 \%(\mathrm{v} / \mathrm{v})$ glycerol in liquid nitrogen. The renovation of the cells was made each 12 months on nutrient agar, at $28^{\circ} \mathrm{C}$ during $48 \mathrm{~h}$; to maintain of biological viability.

The non-pathogenic antagonist bacteria, Pseudomonas sp. strain LN, was isolated from leaves with citrus canker lesions collected in Astorga, PR, Brazil [12]. The procedure of storing and cell maintenance was the same as for Xac 306, except the culture medium that was tryptic soil agar (TSA) plus copper chloride (100 $\left.\mathrm{mg} \cdot \mathrm{L}^{-1}\right)$. Cain and collaborators [13] suggests that some bacteria isolated from culture media added copper might produce antagonistic substances.

\subsection{Inoculum}

The strain LN inoculum was prepared from cultures grown for $48 \mathrm{~h}$ at $28^{\circ} \mathrm{C}$ on TSA plus copper chloride. Cells were removed from the surface of the growth medium with a sterile loop and suspended in sterile phosphate buffer $\left(\mathrm{KH}_{2} \mathrm{PO}_{4} 1 \mathrm{~g} ; \mathrm{K}_{2} \mathrm{HPO}_{4} 1.5 \mathrm{~g}\right.$; distilled water $1000 \mathrm{~mL}, \mathrm{pH}$ 7.0). Inoculum concentration was determined spectrophotometricaly $(\lambda=590 \mathrm{~nm})$ and adjusted to a final density of $10^{8} \mathrm{CFU} \cdot \mathrm{mL}^{-1}$ using sterile phosphate buffer.

Pathogen inoculum was prepared from cultures of Xac 306 grown on nutrient agar for $48 \mathrm{~h}$ at $28^{\circ} \mathrm{C}$. Xac 306 was prepared as described above, and the pathogen final concentration was adjusted to $10^{8} \mathrm{CFU} \cdot \mathrm{mL}^{-1}$.

\subsection{Antagonistic Bacterial Extract}

Bacteria strain LN was grown in TSB plus copper (Cain et al., 2000) (1500 mL) and incubated in a shaker at $28^{\circ} \mathrm{C}$ and $100 \mathrm{rpm}$, during 15 days. After bacterial growth, the medium was centrifuged in a refrigerated centrifuge $\left(9000 \mathrm{rpm}\right.$ at $\left.4^{\circ} \mathrm{C}\right)$, to obtain the secondary metabolites in the supernatant. The solid residue was discarded.

Aliquots of $500 \mathrm{~mL}$ were extracted with ethyl acetate $(500 \mathrm{~mL})$ in separation funnel. This process was repeated five times. The organic phase, called acetate fraction (AF $0.031 \mathrm{~g}$ ) was concentrated in rotatory evaporator and lyophilized. The lyophilized powder was suspended in methanol and filtered; the filtrate was lyophilized to yield the acetate methanol fraction (AMF $0.022 \mathrm{~g}$ ). The AMF was suspended in ethyl acetate, filtered and the filtrate was lyophilized; originating the acetate-ethyl acetate fraction (AEF $0.020 \mathrm{~g}$ ). 


\subsection{Vacuum Liquid Chromatography (VLC)}

VLC was performed using a glass column (20 mm diameter $\times 140 \mathrm{~mm}$ height), silica gel 60 (0.063 - $0.200 \mathrm{~mm}$, Merck), vacuum at $\sim 380 \mathrm{~mm} \mathrm{Hg}$ and the organic solvents were hexane, dichloromethane, ethyl acetate, methanol, methanol plus distilled water 1:1 (v/v), and distilled water; in this order [14]. Nine grams of silica gel were packaged in the glass column; afterwards in the top of the column $1.55 \mathrm{~g}$ of AEF fraction was added. Twenty milliliters of each solvent was added four times. The respective organic phases were collected and dried originating the fractions hexane (VLC1 $0.0014 \mathrm{~g}$ ), dichloromethane (VLC2 $0.1541 \mathrm{~g}$ ), ethyl acetate (VLC3 $0.5659 \mathrm{~g}$ ), methanol (VLC4 0.7217 g) water: methanol mix v/v (VLC5 0.0197 g) and distilled water (VLC6 0.0022 g). All organic phases were concentrated in rotatory evaporator and lyophilized.

\subsection{Agar Well Diffusion Assay}

The experiments were performed utilizing four replications per treatment (fractions). Petri plates containing nutrient agar were inoculated with a suspension of $10^{8} \mathrm{CFU}$ of Xac 306 in pour plate. A $150 \mu \mathrm{L}$ aliquot of AMF, EAF and all fractions of VLC were tested in a concentration of 0.01 at $0.0001 \mathrm{mg} \cdot \mathrm{mL}^{-1}$ in wells of $9 \mathrm{~mm}$ diameter. The plates were incubated at $28^{\circ} \mathrm{C}$ during $48 \mathrm{~h}$ and control was used distilled water for each tested fraction.

\subsection{Minimum Inhibitory Concentration}

In this step the experiments was performed in duplicate. The fractions, which showed more antimicrobial activity against Xac 306 (EAF, VLC2, VLC3 and VLC4) in the item 2.3, were selected to the next step. In this test a 24-well tissue culture plate containing $1.9 \mathrm{~mL}$ of nutrient broth was inoculated with of Xac $306\left(10^{8} \mathrm{CFU}^{\mathrm{mL}} \mathrm{m}^{-1}\right)$ per well. Two-fold dilution of fractions concentration such as 5000; 2500; 1250; 625; 312.5; 156.25; 78.12; 39.06; 19.53; and $9.76 \mu \mathrm{g} \cdot \mathrm{mL}^{-1}$ were tested. Distilled water as used as control for each fraction tested. The minimal inhibitory concentration (MIC) was defined as the lowest concentration of FAM, FAE and VLC fractions which had non-bacterial growth after incubation. To determine the minimal inhibitory concentration, $50 \mu \mathrm{L}$ of each wells with no visible growth were picked up from each well, and inoculated on nutrient agar and incubated at $28^{\circ} \mathrm{C}$ during $48 \mathrm{~h}$ to check viable cells of Xac 306 cells observing the presence or absence of Xac 306 colony in Petri dishes.

\subsection{Cytotoxicity Assay}

Epithelial cells of human larynx carcinoma ATCCL CCL-23 (HEp-2) were grown in DMEN (GiBco ${ }^{\mathrm{TM}}$ ), supplemented with $10 \%$ fetal bovine serum and treated with $100 \mu \mathrm{g} \cdot \mathrm{mL}^{-1}$ of streptomycin, $100 \mathrm{units} \cdot \mathrm{mL}^{-1}$ of penicillin and $2.5 \mu \mathrm{g} \cdot \mathrm{mL}^{-1}$ of fungizone. Cells were kept at $-80^{\circ} \mathrm{C}$.

The fractions effects on cell viability were analyzed using the colorimetric MTT (3-[4, 5-dimethilthiazol-2yl]-2, 5-diphenil tetrazolium bromide) method (MTT-based assay kit, Sigma Chem. Co.) according to the manufacturer's instructions. Cells were grown in microplates with 96-wells for $48 \mathrm{~h}$. After attachment to plates, the supernatant of each well was removed carefully and replace with $100 \mu \mathrm{L}$ of fresh DMEN containing different concentrations of EAF, VLC2, and VLC3. All the fractions were tested in the same concentration (50; 10; 5; 1; 0.5 and $0.05 \mu \mathrm{g} \cdot \mathrm{mL}^{-1}$ ). The plates were incubated for $72 \mathrm{~h}$ at $37^{\circ} \mathrm{C}$ in a $5 \% \mathrm{CO}_{2}$ chamber with humidified atmosphere. The absorbance of each well was measured in a microplate reader at $490 \mathrm{~nm}$ and $630 \mathrm{~nm}$. The experiment was performed in four replicate per fraction.

\subsection{Genotoxicity Test}

HEp-2 cells were grown as adherent monolayers in $25 \mathrm{~cm}^{2}$, sterile disposable flasks utilizing Dulbecco's Modified Eagles's Medium (DMEM F12) (Gibco BRL) supplemented with 10\% fetal bovine serum (Gibco BRL) for the fortification of growth factors. The cultures were maintained in a BOD incubator at $37^{\circ} \mathrm{C}$. The cells were grown for two complete cell cycles ( $24 \mathrm{~h}$ ) before being treated according to the protocol for each test.

The alkylating agent ethylmethane sulfonate (EMS) (Acros Organics) is a well-known chemical mutagen. It was used for the positive control in the determination of genotoxicity and cytotoxicity and to cause mutations at the hgprt locus. EMS was dissolved in $\mathrm{Ca}^{2+}$ and $\mathrm{Mg}^{2+}$ free phosphate-buffered saline (PBS), $\mathrm{pH} 7.4$, just before use. The final concentration of this agent in the cultures was $155 \mu \mathrm{g} \cdot \mathrm{mL}^{-1}$ in the comet assay. 
The general procedure for the genotoxicity test (comet assay) followed the method described by Speit and Hartmann [15] wich is based on the original work of [16] with some modifications. Approximately $1.8 \times 10^{5}$ cells were grown in $2.5 \mathrm{~mL}$ culture tubes for $24 \mathrm{~h}$. After incubation, the cells were washed with $5 \mathrm{~mL}$ PBS and treated in medium without serum at $37^{\circ} \mathrm{C}$ for $3 \mathrm{~h}$. At the end of treatment, the cells were washed, trypsinized and re-suspended in the fresh medium. The cells were then centrifuged (900 rpm) for 5 min to remove the supernatant leaving $300 \mu \mathrm{L}$ for re-suspension of the pellet. Liquified agarose, $120 \mu \mathrm{L}$, was then added to a $20 \mu \mathrm{L}$ aliquot of cell suspension. The sample was applied to a microscope slide previously gelatinized and covered with a coverslip. After $20 \mathrm{~min}$ at $4^{\circ} \mathrm{C}$, the coverslip was removed and the slides were immersed for $60 \mathrm{~min}$ at $4^{\circ} \mathrm{C}$ in lysis solution containing $89 \mathrm{~mL}$ of lysis stock solution (2.5 M NaCl, $100 \mathrm{mM}$ EDTA, $10 \mathrm{mM}$ Tris, $\sim 8 \mathrm{~g}$ NaOH to obtain a $\mathrm{pH}$ of 10, $890 \mathrm{~mL}$ of deionized water, and $1 \%$ sodium lauryl sarcosinate), $1 \mathrm{~mL}$ Triton X-100 (Merck) and $10 \mathrm{~mL}$ DMSO.

The slides were then placed in an electrophoresis chamber in a chilled bath and maintained submersed in alkaline running buffer $(\mathrm{pH}>13)(5 \mathrm{~mL} 200 \mathrm{mM}$ EDTA, $30 \mathrm{~mL} 10 \mathrm{~N} \mathrm{NaOH}$ and $965 \mathrm{~mL}$ of deionized water at $4^{\circ} \mathrm{C}$ ) for $20 \mathrm{~min}$, to examine for single strand breaks. The slides were electrophoresed for $20 \mathrm{~min}$ at $25 \mathrm{~V}$ and $300 \mathrm{~mA}$. The slides were then covered with neutralizing solution (0.4 M Tris-HCL, $\mathrm{pH} 7.5)$ for $15 \mathrm{~min}$ at $22^{\circ} \mathrm{C}$. Finally, the slides were submersed in absolute ethanol for $10 \mathrm{~min}$ at $22^{\circ} \mathrm{C}$. All the procedures were carried out under low light to avoid extra DNA damage by the action of the light. The material was stained with $80 \mathrm{~L}$ ethidium bromide (20 $\left.\mu \mathrm{g} \cdot \mathrm{mL}^{-1}\right)$ and examined with fluorescence microscopy using an excitation filter of 515 - 560 $\mathrm{nm}$ and an emission filter of $590 \mathrm{~nm}$.

The extend and distribution of DNA damage indicated by the comet assay was evaluated by examining at least 100 randomly selected and no-overlapping cells on the slides per treatment. These cells were scored visually according the presence or absence of nucleus tail. The results were evaluated by the statitical tests analysis of variance (ANOVA) and Tukey's test at $\mathrm{p}<0.05$, with the experimental criterion being the significance of the response in relation on the negative control in genotoxicity assay, and in relation to the positive control.

\subsection{Antimicrobial Activity Test in Orange Leaves}

Plants of $C$. sinensis cv. Valencia were used in the greenhouse experiments under the following conditions: $28^{\circ} \mathrm{C} / 22^{\circ} \mathrm{C}$ and $10 \mathrm{~h} / 14 \mathrm{~h}$ day/night respectively and $80 \%$ relative humidity. Plants were watered three times at each seven days and fertilized twice a month with Hewitt solution for non-legume [17].

Orange leaves with 15 days old were treated with EAF, VLC2, and VLC3 fractions which showed high antimicrobial activity against Xac 306 in a antimicrobial activity assay in 24-well tissue culture plate. All the fractions were applied at the concentration $0.01 \mathrm{~g} \cdot \mathrm{mL}^{-1}$ diluted in distillated water and applied with a hand-sprayer in the abaxial and adaxial leaf surface. The application was realized before or after leaves inoculation with Xac 306.

Plants were subjected to a moist chamber for $24 \mathrm{~h}$ before and after inoculation and kept at greenhouse, in order to stimulate the stomata opening and improve the efficiency of bacterial infection and the action of the treatments. Control plants were sprayed with distilled water. The plants were watered three times a week. The number of citrus canker lesions per leaf was determined 21 days after inoculation to harvest 18 leafs per plant. The average number of lesions was calculated by the equation: $\sum$ no lesions in 18 leaves/ $\sum$ area of 18 leaves. The treatments with the fractions were done before (pre-treatment) and after (post-treatment) the pathogen spraying, in five replications. Analysis of variance was performed on root square-transformed data and means were compared by Tukey multiple range test at $\mathrm{P}<0.05$. Data were transformed by $\sqrt{\mathrm{y}+0.5-\mathrm{SQRT}(y+0.5)}$.

\section{Results}

\subsection{Agar Well Diffusion Assay}

In this experiment antimicrobial activity as tested in all fraction obtained from supernatant of LN culture extracted by ethyl acetate (EAF and AMF) and obtained from EAF fractionation in vacuum liquid chromatography extracted with n-hexane (VLC1), dichloromethane (VLC2), ethyl acetate (VLC3), methanol (VLC4), water: methanol mix v:v (VLC5), and distilled water (VLC6). In this experiment only EAF, VLC2, VLC3, and VLC4 showed antimicrobial activity against Xac 306 (Table 1). However different effects were observed. EAF and VLC2 fractions had the highest antimicrobial effect were found halo with $30 \mathrm{~mm}$ of diameter on $0.01 \mathrm{mg} \cdot \mathrm{mL}^{-1}$, 
Table 1. Effects of fraction derived from the supernatant of LN culture extracted with methanol (AMF) and ethyl acetate (EAF), and fractions obtained from vacuum liquid chromatography extracted with n-hexane (VLC1), dichloromethane (VLC2), ethyl acetate (VLC3), methanol (VLC4), water: methanol mix vol:vol (VLC5) and distilled water (VLC6) in ten-fold dilution on the growth of Xac 306 in nutrient agar in Petri dishes.

\begin{tabular}{|c|c|c|}
\hline Fraction & Concentration $\left(\mathrm{mg} \cdot \mathrm{mL}^{-1}\right)$ & Halo diameter (mm) \\
\hline \multirow{3}{*}{ AMF } & 0.01 & \\
\hline & 0.001 & - \\
\hline & 0.0001 & \\
\hline \multirow{3}{*}{$\mathrm{AEF}$} & 0.01 & 30 \\
\hline & 0.001 & 12 \\
\hline & 0.0001 & - \\
\hline \multirow{3}{*}{ VLC1 } & 0.01 & \\
\hline & 0.001 & - \\
\hline & 0.0001 & \\
\hline \multirow{3}{*}{ VLC2 } & 0.01 & 30 \\
\hline & 0.001 & 12 \\
\hline & 0.0001 & - \\
\hline \multirow{3}{*}{ VLC3 } & 0.01 & 20 \\
\hline & 0.001 & 10 \\
\hline & 0.0001 & - \\
\hline \multirow{3}{*}{ VLC4 } & 0.01 & 10 \\
\hline & 0.001 & - \\
\hline & 0.0001 & - \\
\hline \multirow{3}{*}{ VLC5 } & 0.01 & \\
\hline & 0.001 & - \\
\hline & 0.0001 & \\
\hline \multirow{3}{*}{ VLC6 } & 0.01 & \\
\hline & 0.001 & - \\
\hline & 0.0001 & \\
\hline
\end{tabular}

(-) no inhibition zone.

in the same concentration VLC3 presented halo with $20 \mathrm{~mm}$, and VLC4 $10 \mathrm{~mm}$. The $0.001 \mathrm{mg} \cdot \mathrm{mL}^{-1}$ the EAF, VLC2 and VLC3 showed the same antimicrobial effect, and VLC4 did not have any effect (Table 1).

\subsection{Minimum Inhibitory Concentration}

In this experiment was tested the bactericidal effect only a fractions which showed antimicrobial effect against Xac 306. EAF fraction showed bactericidal effect in concentration of 5000 until $312.5 \mu \mathrm{g} \cdot \mathrm{mL}^{-1}$. On the other hand in VLC2 and VLC3 the bactericidal effect was observed also in $156.25 \mu \mathrm{g} \cdot \mathrm{mL}^{-1}$. However VLC4 showed bactericidal effect only in 5000 and $2500 \mu \mathrm{g} \cdot \mathrm{mL}^{-1}$ (Table 2).

\subsection{Cytotoxicity Assay}

The cytotoxicity capacity of EAF, VLC2 and VLC3 fractions were tested. In the ten-fold dilutions curves the three fractions showed similar cytotoxicity effects on the different concentrations evaluated (Figure 1). Similar 
Table 2. Minimum Inhibitory Concentration of derived from the second extraction with ethyl acetate (EAF) of supernatant of LN culture and fractions obtained from vacuum liquid chromatography extracted with dichloromethane (VLC2), ethyl acetate (VLC3), and methanol (VLC4) in two-fold dilution on the growth of Xac 306.

\begin{tabular}{|c|c|c|c|c|}
\hline \multirow{2}{*}{ Concentration $\left(\mu \mathrm{g} \cdot \mathrm{mL}^{-1}\right)$} & \multicolumn{4}{|c|}{ Fractions } \\
\hline & EAF & VLC2 & VLC3 & VLC4 \\
\hline 5000 & + & + & + & + \\
\hline 2500 & + & + & + & + \\
\hline 1250 & + & + & + & - \\
\hline 625 & + & + & + & - \\
\hline 312.5 & + & + & + & - \\
\hline 156.25 & - & + & + & - \\
\hline 78.12 & - & - & - & - \\
\hline 39.06 & - & - & - & - \\
\hline 19.53 & - & - & - & - \\
\hline 9.76 & - & - & - & - \\
\hline
\end{tabular}

$(+)$ growth inhibition and $(-)$ no inhibition.

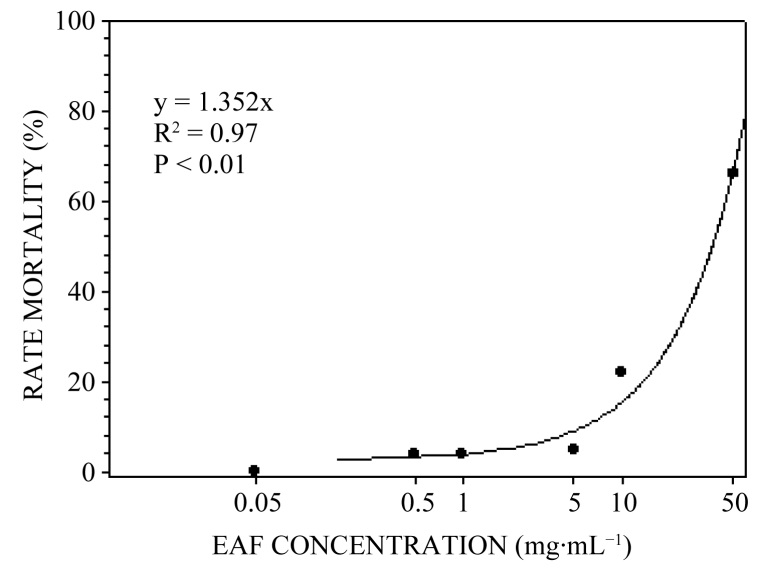

(a)

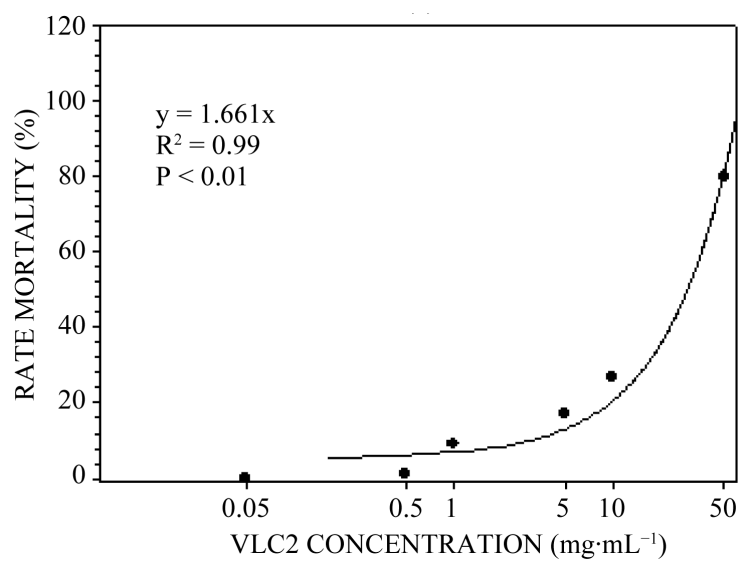

(b)

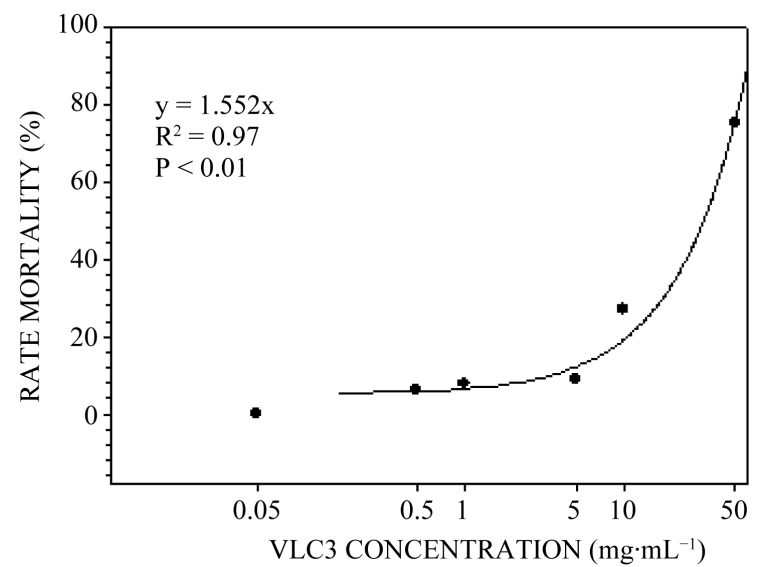

(c)

Figure 1. Correlation between rate of cell mortality and fractions concentrations. (a) [EAF] Fraction from the second extraction with ethyl acetate of supernatant of bacterial culture; (b) [VLC2] Fraction derived from de vacuum liquid chromatography extracted with dichloromethane; (c) [VLC3] Fraction derived from de vacuum liquid chromatography extracted with ethyl acetate. 
results were obtained for $\mathrm{CC}_{50}$ which was calculated using the regression equation from each one, and the three fractions EAF, VLC2 and VLC3 showed CC50 values approximated 36.98; 30.09 and $32.22 \mu \mathrm{g} \cdot \mathrm{mL}^{-1}$, respectively.

\subsection{Genotoxicity Assay}

Figure 2 present the data for genotoxicity, for the concentrations $1,0.1$ and $0.05 \mu \mathrm{g} \cdot \mathrm{mL}^{-1}$ of the fractions EAF, VLC2 and VLC3. No DNA migration was found at the EAF, VLC2 and VLC3 fractions on its concentrations tested, compared with positive control. The total cells with damage in the comet assay did not differ from the negative control, except for VLC3 on the high concentration $\left(1 \mu \mathrm{g} \cdot \mathrm{mL}^{-1}\right)$. Antimicrobial activity test in orange leaves.

\subsection{Antimicrobial Activity Test in Orange Leaves}

The fractions EAF, VLC2, and VLC3 were tested in the greenhouse experiments to check its capacity to reduce the area of citrus canker lesions formed on leaves. The strategies used to treat the leaves with fractions before or after infestation with Xac 306 did not show any inhibitory effect (data not show). However, the leaves treated with CLV3 fraction had 40\% less lesions area when compared with control. The fractions EAF and VLC2 did not differed significantly to the control (Figure 2).

\section{Discussion}

In the previous studies was testing the effect of secondary metabolite produced by Pseudomonas aeruginosa strain LV on different phytopathogenic bacteria [8]-[10], and other pathogenic bacteria [18] [19]. In the present study was evaluate the effect secondary metabolites produced by Pseudomonas sp. LN strain on the severity of citrus canker lesion caused in C. sinensis cv. Valencia by Xac 306.

The results shows that antibiosis of fractions from secondary bacterial metabolites extracted with different organic solvents against Xac 306 population in vitro, as well as its ability to control the severity of citrus canker in planta. EAF, VLC2 and VLC3 had highest antimicrobial efficiency to the control of Xac 306 in vitro, when compared with the others fractions tested (AMF, EAF, VLC1, VLC4, VLC5 and VLC6). The highest effect observed was obtained from compounds soluble first at all in ethyl acetate (EAF). When the EAF fraction was

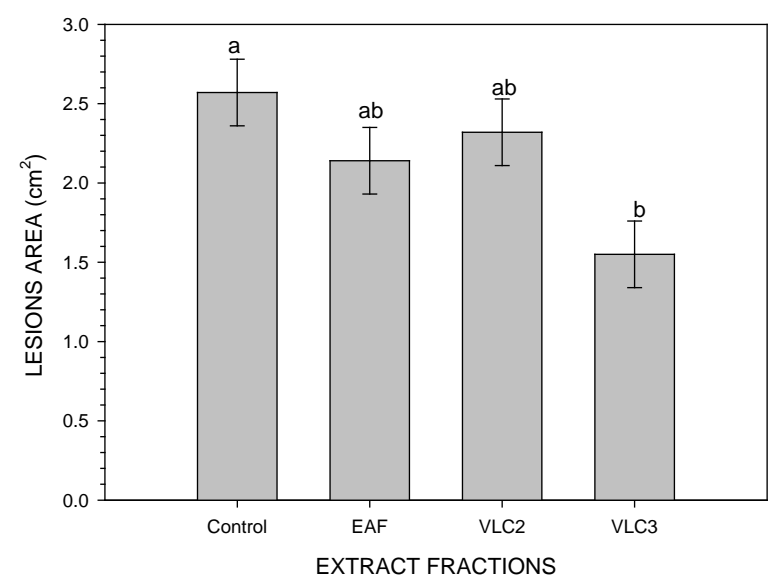

Figure 2. Control of citrus canker lesion formation by Xac 306 on leaf of orange trees (C. sinensis pv. Valencia) by fractions derived from the second extraction with ethyl acetate (EAF) of supernatant of LN culture and fractions obtained from vacuum liquid chromatography extracted with dichloromethane (VLC2), ethyl acetate (VLC3) in a concentration of $10 \mathrm{mg} \cdot \mathrm{mL}^{-1}$. Values are the means of 5 replicates. Means for each treatment with the same letter are not significantly different of Tukey test $(\mathrm{P} \leq 0.05)$. 
fractionated by vacuum liquid chromatography the bactericidal effect also was observed in another fraction obtained from dichloromethane (VLC2). However the highest bactericidal effect against Xac 306 after chromatography assay still was found in ethyl-acetate fraction.

The concentrations of EAF, VLC2, and VLC3 fractions considered non-cytotoxic were far below the concentrations was found bactericidal effects in the three assays carried out in the paper. The maximum non-cytotoxic concentrations observed for mammals cell was $10 \mu \mathrm{g} \cdot \mathrm{mL}^{-1}$ and to Xac 306 was $156.25 \mu \mathrm{g} \cdot \mathrm{mL}^{-1}$ in vitro, and in planta the amount which was observed antimicrobial effect was $10,000 \mu \mathrm{g} \cdot \mathrm{mL}^{-1}$. However the leaves treated did not have any aspects of toxicity; like color changes or morphological aspects.

In the comet assay were tested non-cytotoxic concentrations for the fractions EAF, VLC2 and VLC3, to better evaluated induced DNA damage [20]. Only VLC3 in the concentration of $1 \mu \mathrm{g} \cdot \mathrm{mL}^{-1}$ demonstrated cytotoxicity and DNA migration could not be observed. Ours results showed that these fractions and its concentrations tested had no genotoxic effects on HEp-2 cells.

The application (before or after sprayed Xac 306) of the fractions did not affect the occurrence of citrus canker lesions. After one day on the leaf Xac 306 is not fully established [21]. Despite the fact that the fraction VLC3 decreased significantly the citrus canker lesions when compared with control, and showing a possibility to control the severity of citrus canker. However, the level of this control is not enough to justify the solution of citrus canker disease, before a field experiment will not carried out to verify that in this experimental conditions we can observed the same effects that was observed in a greenhouse experiment, that is the challenge for the future.

\section{Conclusions}

In conclusion, EAF, VLC2, VLC3 and VLC4 fractions had antagonistic effect against Xac 306 in vitro. AEF, VLC2 and VLC3 demonstrated non-cytotoxic effect in concentration of $10 \mu \mathrm{g} \cdot \mathrm{mL}^{-1}$ on HEp-2 cells. VLC3 had significant results in the control of foliar citrus canker lesions caused in $C$. sinensis cv. Valencia in greenhouse conditions.

On the other hand, other studies need to be carried out to determine the best conditions for application to get the high efficiency of the bactericidal effect of the VLC3 fraction also including EAF and VLC3 as well as the identification and purification secondary metabolites extracted from the LN supernatant. These determinations are very important to evaluate the possible impact of these metabolites on the environment, given that the biological nature of the secondary metabolites not necessarily assures that they are not hazardous to the environment [22].

\section{Acknowledgements}

To the National Council of Scientific and Technological Development (CNPq) who enabled the execution of this study by conceding PIBIC, M.Sc., PhD and Productivity in research grants.

\section{References}

[1] Gottwald, T.R., Sun, X., Riley, T., Graham, J.H., Ferrandino, F. and Taylor, E.L. (2002) Geo-Referenced Spatiotemporal Analysis of the Urban Citrus Canker Epidemic in Florida. Phytopathology, 92, 361-377. http://dx.doi.org/10.1094/PHYTO.2002.92.4.361

[2] Schubert, T.S. and Sun, X. (2003) Bacterial Citrus Canker. Plant Pathology Circular, 377, 1-6.

[3] Schubert, T.S., Rizbi, S.A., Gottwald, T.R., Graham, J.H. and Dixon, W.N. (2001) Meeting the Challenge of Eradicating Citrus Canker in Florida-Again. Plant Disease, 85, 340-356. http://dx.doi.org/10.1094/PDIS.2001.85.4.340

[4] Rudolph, K. (1993) Infection of the Plant by Xanthomonas. In: Swings, J.G. and Civerolo, E.L., Eds., Xanthomonas, Chapman and Hall, London, 193-264. http://dx.doi.org/10.1007/978-94-011-1526-1 4

[5] Koizumi, M. (1985) Citrus Canker: The World Situation. In: Timmer, L.W., Ed., Citrus Canker: An International Perspective, University of Florida, Institute of Food and Agricultural Science, Gainesville, 2-7.

[6] Quimby, P.C., King, L.R. and Grey, W.E. (2002) Biological Control as Means of Enhancing the Sustainability of Crop/Land Management Systems. Agriculture, Ecosystems and Environment, 88, 147-152. http://dx.doi.org/10.1016/S0167-8809(01)00251-1

[7] Földes, T., Bánhegyi, I., Herpai, Z., Varga, L. and Szigeti, J. (2000) Isolation of Bacillus Strains from Rhizosphere of Cereals and in Vitro Screening for Antagonism against Phytopatogenic, Food-Borne Pathogenic and Spoil-Age Microorganisms. Journal of Applied Microbiology, 89, 840-846. http://dx.doi.org/10.1046/j.1365-2672.2000.01184.x 
[8] de Oliveira, A.G., Murate, L.S., Spago, F.R., Lopes, L.D., Beranger, J.P.D., Martin, J.A.B.S., Nogueira, M.A., de Mello, J.C.P., Andrade, C.G.T.D. and Andrade, G. (2011) Evaluation of the Antibiotic Activity of Extracellular Compounds Produced by the Pseudomonas Strain against the Xanthomonas citri pv. citri 306 Strain. Biological Control, 56, 125-131. http://dx.doi.org/10.1016/j.biocontrol.2010.10.008

[9] Lopes, L.P., Oliveira, A.G., Beranger, J.P.O., Gois, C.G., Vasconcellos, F.C.S., San Martin, J.A.B., Andrade, C.G.T.J., Mello, J.C.P. and Andrade, G. (2012) Activity of Extracellular Compounds of Pseudomonas sp. against Xanthomonas axonopodis in Vitro and Bacterial Leaf Blight in Eucalyptus. Tropical Plant Pathology, 37, 233-238. http://dx.doi.org/10.1590/S1982-56762012000400001

[10] Vasconcellos, F.C.S., de Oliveira, A.G., Lopes-Santos, L., Beranger, J.P.O., Cely, M.V.T., Simionato, A.S., Pistori, J.F., Spago, F.R., Mello, J.C.P., San Martin, J.A.B., Andrade, C.G.T.J. and Andrade, G. (2014) Evaluation of Antibiotic Activity Produced by Pseudomonas aeruginosa LV Strain against Xanthomonas arboricola pv. pruni. Agricultural Sciences, 5, 71-76. http://dx.doi.org/10.4236/as.2014.51008

[11] da Silva, A.C.R., Ferro, J.A., Reinach, F.C., Farah, C.S., Furlan, L.R., Quaggio, R.B., Monteiro-Vitorello, C.B., Sluys, M.A.V., Almeida, N.F., Alves, L.M.C., do Amaral, A.M., Bertolini, M.C., Camargo, L.E.A., Camarotte, G., Cannavan, F., Cardozo, J., Chambergo, F., Ciapina, L.P., Cicarelli, R.M.B., Coutinho, L.L., Cursino-Santos, J.R., El-Dorry, H., Faria, J.B., Ferreira, A.J.S., Ferreira, R.C.C., Ferro, M.I.T., Formighieri, E.F., Franco, M.C., Greggio, C.C., Gruber, A., Katsuyama, A.M., Kishi, L.T., Leite, R.P., Lemos, E.G.M., Lemos, M.V.F., Locali, E.C., Machado, M.A., Madeira, A. M.B.N., Martinez-Rossi, N.M., Martins, E.C., Meidanis, J., Menck, C.F.M., Miyaki, C.Y., Moon, D.H., Moreira, L.M., Novo, M.T.M., Okura, V.K., Oliveira, M.C., Oliveira, V.R., Pereira, H.A., Rossi, A., Sena, J.A.D., Silva, C., de Souza, R.F., Spinola, L.A.F., Takita, M.A., Tamura, R.E., Teixeira, E.C., Tezza, R.I.D., Trindade dos Santos, M., Truffi, D., Tsai, S.M., White, F.F., Setubal, J.C. and Kitajima, J.P. (2002) Comparison of the Genomes of Two Xanthomonas Pathogens with Differing Host Specificities. Nature, 417, 459-463. http://dx.doi.org/10.1038/417459a

[12] Rampazo, L.G.L. (2007) Evaluation of the Effect of Biological Agents and Their Products into the Incidence of Citrus Canker Lesions. Master Thesis, University of Londrina, Londrina.

[13] Cain, C.C., Henry, A.T., Waldo III, R.H., Casida Jr., L.J. and Falkinham III, J.O. (2000) Identification and Characteristics as a Novel Burkholderia Strain with Broad-Spectrum Antimicrobial Activity. Applied and Environmental Microbiology, 66, 4139-4141. http://dx.doi.org/10.1128/AEM.66.9.4139-4141.2000

[14] Mello, J.C.P. and Petrovick, P.R. (2000) Quality Control of Baccharis trimera (Less.) DC. (Astearaceae) Hydroalcoholic Extracts. Acta Farmaceutica Bonaerense, 19, 211-215.

[15] Speit, G. and Hartmann, A. (1999) The Comet Assay (Single-Cell Gel Test), a Sensitive Genotoxicity Test for the Detection of DNA Damage and Repair. In: Henderson, D.S., Ed., Methods in Molecular Biology: DNA Repair ProtocolsEukaryotic Systems, Humana Press, Totowa, 203-211.

[16] Singh, N.P., McCoy, M.T., Tice, R.R. and Schneider, E.L. (1988) A Simple Technique for Quantitation of Low Levels of DNA Damage in Individual Cells. Experimental Cell Research, 175, 184-191. http://dx.doi.org/10.1016/0014-4827(88)90265-0

[17] Hewitt, E.J. (1966) Sand and Water Culture Methods Used in Study of Plant Nutrition. 2nd Edition England, Commonwealth Agricultural Bureaux, Farnham Royal, Bucks, England.

[18] Cardozo, V.F., de Oliveira, A.G., Nishio, E.K., Perugini, M.R.E., Andrade, C.G.T.J., Silveira, W.D., Durán, N., Andrade, G., Kobayashi, R.K.T. and Nakazato, G. (2013) Antibacterial Activity of Extracellular Compounds Produced by a Pseudomonas Strain against Methicillin-Resistant Staphylococcus aureus (MRSA) Strains. Annals of Clinical Microbiology and Antimicrobials, 12, 1-8.

[19] Góis, C.G.M., Lopes-Santos, L., Beranger, J.P.O., de Oliveira, A.G., Spago, F.R. and Andrade, G. (2013) The Control of Lactobacillus sp. by Extracellular Compound Produced by Pseudomonas aeruginosa in the Fermentation Process of Fuel Ethanol Industry in Brazil. Journal of Sustainable Bioenergy Systems, 3, 194-201. http://dx.doi.org/10.4236/jsbs.2013.33027

[20] Hartmann, A. and Speit, G. (1997) The Contribution of Cyto-Toxicity to DNA-Effects in the Single Cell Gel Test (Comet Assay). Toxicology Letters, 90, 183-188. http://dx.doi.org/10.1016/S0378-4274(96)03847-7

[21] Koizumi, M. (1988) Mechanisms of Disease Development and Host Resistance of Citrus Canker. In: Rossetti, V., Ed., Processing of International Symposium of Citrus Canker, Blight and Similar Diseases, Fundação Cargil, Campinas, 138-145.

[22] Cook, R.J., Bruckart, W.L., Coulson, J.R., Goettel, M.S., Humber, R.A., Lumsdem, R.D., Maddox, J.V., Mcmanus, M.L., Moore, L., Meyer, S.F., Quimby, P.C., Stack Jr., J.P. and Vaughn, J.L. (1996) Safety of Microorganisms Intended for Pest and Plant Disease Control: A Framework for Scientific Evaluation. Biological Control, 7, 333-351. http://dx.doi.org/10.1006/bcon.1996.0102 